\title{
Conversion of Rice Straw into Methane Gas using Zeolites
}

\author{
Takaaki Wajima and Tomonobu Sakakibara \\ Department of Urban Environment Systems, Graduate School of Engineering, Chiba University, \\ 1-33, Yayoi-cho, Inage-ku, Chiba, 263-8522, Japan.
}

\begin{abstract}
In Japan, there is a large amount of biomass waste from agriculture to be used as resources. In this study, we examined the conversion of rice straw into methane gas by thermal decomposition using zeolite catalysts. Four types of zeolites, $\mathrm{NaA}, \mathrm{NaX}, \mathrm{NaY}$ and $\mathrm{HY}$, with different properties, crystal structure, exchangeable cation and $\mathrm{Si} / \mathrm{Al}$ ratio were used as catalysts. The mixture of rice straw and zeolite was added into the reactor, and the reactor was heated $400{ }^{\circ} \mathrm{C}$ for $1 \mathrm{~h}$ in nitrogen atmosphere. The amount and composition of the gas generated during the heating, and the weight of residue were examined. The results show the conversion of rice straw into methane gas can be improved using zeolites, and faujasite zeolites having $\mathrm{Na}$ cation, $\mathrm{NaX}$ and $\mathrm{NaY}$, could convert rice straw into the largest amount of methane gas in this experiment. With increasing the heating temperature, production of methane gas promotes due to the promotion of decomposition reaction. The valuable gas including methane can be obtained from rice straw by heating at higher than $600{ }^{\circ} \mathrm{C}$ for $30 \mathrm{~min}$ with $\mathrm{NaY}$ addition of same weight to rice straw.
\end{abstract}

Key words: Rice straw, Methane gas, Zeolites, pyrolysis

\section{INTRODUCTION}

As we face the problems of global warming and climate change, substantial research and development has focused on the use of biomass as an alternative to fossil fuels. The widespread availability of biomass has been widely recognized, as has its potential to supply much larger amounts of useful energy with fewer environmental impacts than fossil fuels [1].

Biomass is one of the promising forms of clean and green fuel that can meet day to day energy requirements, and its use predates the use of fossil fuels such as petroleum, natural gas and coal. Biomass makes a significant contribution (about $14 \%$ ) to global renewable energy utilization, while in rural areas of developing countries this contribution is up to $90 \%$. Since around $90 \%$ the world production is expected to reside in developing countries by 2050 , biomass is likely to remain a major source of energy for those large populations [2-4].

In our country for the recycling society formation, reuse of the biomass waste is an important problem. Energy supply in Japan is supported by the import of fossil fuel such as coal, oil and natural gas. Furthermore, after East Japan great earthquake disaster of 2011, the dependence of thermal power generation increases. In waste biomass utilization, "a biomass utilization promotion fundamental law" put into operation in June, 2009. Availability of non-edible biomass products, such as rice husk, rice straw and so on, for heat utilization is one of the method for use of biomass.

The biomass has low energy density to get energy efficiently, and many conversion technology of biomass into high-value products were studied. Biomass can be converted into higher-value products via either biological or thermochemical processes [5-7]. Biological conversion of low-value lignocelluloseic biomass still faces challenges related to low economy and efficiency [5]. Combustion, pyrolysis and gasification are three main thermochemical conversion methods. Biomass is traditionally combusted to supply heat and power in the process industry. The net efficiency for electricity generation from biomass combustion is usually very low, ranging from $20 \%$ to $40 \%$ [6]. Biomass co-fired in existing combustors is usually limited to $5-10 \%$ of the total feedstock due to concerns about plugging existing coal feed systems [7]. The processes of pyrolysis and gasification are thermochemical conversion technologies to convert

Corresponding Author: Takaaki Wajima, Department of Urban Environment Systems, Graduate School of Engineering, Chiba University, 1-33, Yayoi-cho, Inage-ku, Chiba, 263-8522, Japan., +81-43-290-3507 
biomass feedstock into higher heating value fuel $[8,9]$, and improve for effective production $[10,11]$.

One improvement method to promote the production of high value fuel includes the pyrolysis technique using the zeolite catalyst. Zeolites represent a well-known family of crystalline nano-porous materials with very relevant applications in many fields, especially as catalysts, adsorbents and in the formulation of detergents. Zeolites exhibit a combination of properties very well suited for catalyzing reactions of organic compounds, such as crystalline framework, hydrothermal stability, high surface area, uniform microporosity, hydrophobicity, shape selectivity, acidbase properties, and high resistance against deactivation by carbon deposition [12, 13]. These reasons, among some others, have prompted zeolites to be applied at a commercial scale in a number of relevant sectors. This is the case of the oil refining and petrochemical industries, fine chemistry and pollutants abatement, in which the use of zeolites has allowed developing a high number of commercial applications [14]. Likewise, one emerging field, which has arisen huge interest in recent years, is the use of zeolites as catalysts in biomass valorization processes to produce biofuels and/or biobased chemicals that could lead to the replacement of fossil sources by renewable ones.

In Japan, rice is a staple food. Rice is the second world's largest cereal crop after wheat, and is a widely grown crop in Asia, but rice straw is produced as a by-product of rice production. Every kilogram of grain harvesting is accomplished by the production of rice straw to a tone of $1.0-1.5 \mathrm{~kg}$ [10]. In most parts of rice fields, openfield burning of rice straw is commonly practiced in the region when there is limited time to prepare a field for the next crop. However, open-field burning of crop residues is an uncontrolled combustion process during which air pollutants are emitted into atmosphere. These air pollutants have significant toxicological properties and are potential carcinogens [11]. Although wildfires are prohibited in cultivation fields of most countries, farmers usually keep on burning their crop by-products. Biomass burning is an important source of aerosol particles which may affect local and regional air quality, and also contribute to global climate changes.

In this study, the conversion of rice straw into methane gas using the zeolite catalysts for utilization of the waste as heat sources. Methane is a chemical compound with the chemical formula $\mathrm{CH}_{4}$ (one atom of carbon and four atoms of hydrogen), and is the main constituent of natural gas. We attempted to convert agricultural biomass waste, rice straw, into the valuable fuel gas including mainly methane using typical synthetic zeolites, and the behaviors of gas generation during pyrolysis using zeolites were estimated.

\section{EXPERIMENT}

\section{Rice straw and zeolites}

Raw rice straw, which was collected from a cultivated area in Akita prefecture, Japan, first cut into $1 \mathrm{~cm}$ length, was then washed with distilled water, and dried and stored for use. Properties of rice straw sample are shown in Table 1, which was analyzed using JIS M 8812 and JIS M 8819.

Table 1 Properties of rice straw in this experiment.

\begin{tabular}{ccccccc}
\hline & \multirow{2}{*}{ Moisture } & \multirow{2}{*}{ Ash } & \multicolumn{5}{c}{$\begin{array}{c}\text { Volatile matter } \\
\text { + fixed carbon }\end{array}$} \\
\cline { 4 - 7 } & & & $\mathrm{C}$ & $\mathrm{H}$ & $\mathrm{N}$ & $\mathrm{S}$ \\
\hline $\begin{array}{c}\text { Content } \\
(\%)\end{array}$ & 7.3 & 11.6 & 39.2 & 6.3 & 0.6 & 0.8 \\
\hline
\end{tabular}

Typical four types of synthetic zeolites, HY-type zeolite (HY) (HSZ-320HOA, Tosoh), NaY-type zeolite (NaY) (HSZ-320NAA, Tosoh), NaX-type zeolite (NaX) (Molecular Sieves 13X, Wako) and NaA-type zeolite (NaA) (Molecular Sieves 4A, Wako), were used in this study. These zeolite samples have different properties, such as crystal structures, exchangeable cations and $\mathrm{Si} / \mathrm{Al}$ molar ratios in chemical composition, as shown in Table 2.

Table 2 Properties of zeolites used in this experiment.

\begin{tabular}{ccccc}
\hline & $\mathrm{HY}$ & $\mathrm{NaY}$ & $\mathrm{NaX}$ & $\mathrm{NaA}$ \\
\hline $\begin{array}{c}\text { Crystal } \\
\text { structure }\end{array}$ & & Faujasite & & $\begin{array}{c}\text { Lynde } \\
\text { Type } \\
\mathrm{A}\end{array}$ \\
\hline $\begin{array}{c}\text { Exchangeable } \\
\text { cation }\end{array}$ & $\mathrm{H}^{+}$ & & $\mathrm{Na}^{+}$ & \\
\hline Si/Al raito & & 5.5 & 1.23 & 1 \\
\hline $\begin{array}{c}\text { Average } \\
\text { particle }\end{array}$ & & 6 & 10 & 4 \\
diameter $(\mu \mathrm{m})$ & & 0.3 & 0.5 & 0.2 \\
\hline $\begin{array}{c}\text { Crystal size } \\
(\mu \mathrm{m})\end{array}$ & & 700 & 525 & 650 \\
\hline $\begin{array}{c}\text { Specific } \\
\text { surface area } \\
\left(\mathrm{m}^{2} / \mathrm{g}\right)\end{array}$ & 550 & & & \\
\hline
\end{tabular}

\section{Pyrolysis}

The experimental apparatus used in this study is shown in Figure 1. A mixture of rice straw $(1.0 \mathrm{~g})$ and zeolites $(0-2.0 \mathrm{~g})$ was added into a reactor. The reactor was purged with nitrogen gas at a flow rate of $100 \mathrm{~mL} / \mathrm{min}$ for $30 \mathrm{~min}$ to remove oxygen. After nitrogen substitution, the flow of nitrogen gas at a flow rate 50 $\mathrm{mL} / \mathrm{min}$ and the pyrolysis experiment was performed. Temperature of sample was measured as the setting temperature, and the temperature was increased to the setting temperature $\left(300-700{ }^{\circ} \mathrm{C}\right)$ at a heating rate of 6 ${ }^{\circ} \mathrm{C} / \mathrm{min}$ using an electric heater. After heating at setting temperature for $0-120 \mathrm{~min}$, the reactor was cooled to room temperature, and the residue remained in the reactor after pyrolysis was collected to measure the 
weight of the residue and to be observed. The gases produced during heating were condensed through a water condenser and the condensable gases were recovered as oil. Non-condensable gases, which pass through the condenser, were collected in a gas pack via bubbling of alkaline aqueous solution. The total amount of the generated gas collected in the gas pack was measured by gas meter. The chemical compositions of collected gas were analyzed by gas chromatography (GC) (Shimadzu, GC-2014). The crystal structure of residue was identified with X-ray diffraction (Rigaku, MiniFlex600).

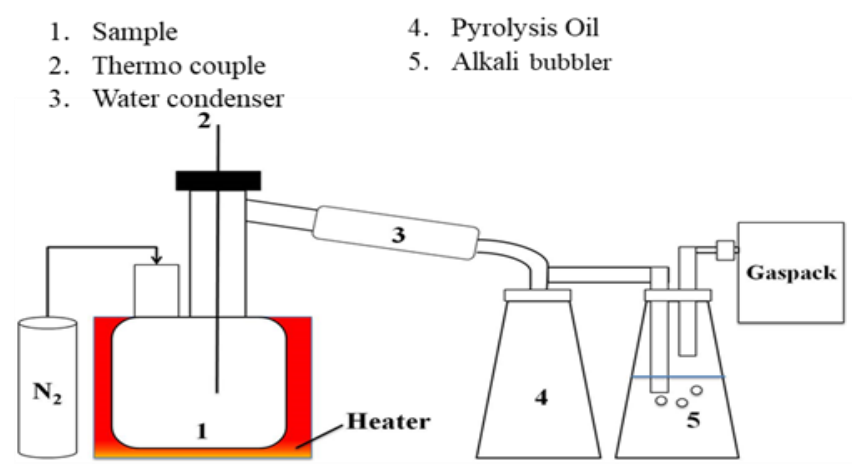

Figure 1 Experimental apparatus used in this experiment

\section{RESULT AND DISCUSSION}

Table 3 shows the amount of the gas generated from rice straw during the experiment. The addition of zeolite is 1 $\mathrm{g}$, setting temperature is $400{ }^{\circ} \mathrm{C}$, and heating time is $1 \mathrm{~h}$. The generated amount of gas from rice straw increases with zeolite addition, and the highest amount of gas was generated using $\mathrm{NaY}$. It is noted that no pyrolysis oil was generated during the experiment.

Table 3 Amount of gas generated during the experiment.

\begin{tabular}{cc} 
& Amount of gas (L) \\
\hline Rice straw & 5.2 \\
\hline Rice straw + HY & 7.4 \\
\hline Rice straw + NaY & 10.9 \\
\hline Rice straw + NaX & 8.2 \\
\hline Rice straw + NaA & 7.5 \\
\hline
\end{tabular}

Figures 3 shows the amounts of various gases generated from rice straw. It is noted that the methane concentration in the generated gas is available for fuel (inflammability limit: 5 - $15 \%$ ). For crystal structure, faujasite-type zeolites, $\mathrm{HY}, \mathrm{NaY}$ and $\mathrm{NaX}$, produce higher amount of methane than Linde type A zeolite, $\mathrm{NaA}$. For cation, $\mathrm{NaX}$ and $\mathrm{NaY}$ can produce higher amount of methane than $\mathrm{HY}$. For $\mathrm{Si} / \mathrm{Al}$ ratio, $\mathrm{NaX}$ and $\mathrm{NaY}$ produce almost same amount of methane gas. It is noted that amount of hydrogen was decreased by zeolite addition.

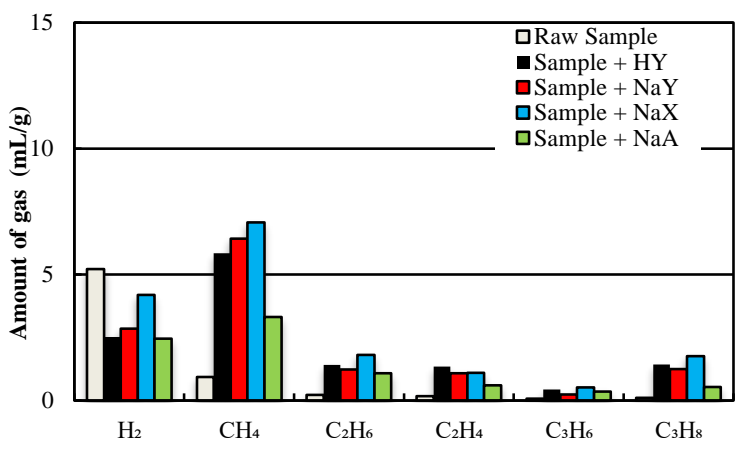

Figure 3 Amounts of various gases generated from rice straw

Figure 4 shows the weight of residue from rice straw after the experiment. The weight of the residue is correlated with amount of the generated gas. A small amount of residue remained in the reactor when a large amount of gas generated.

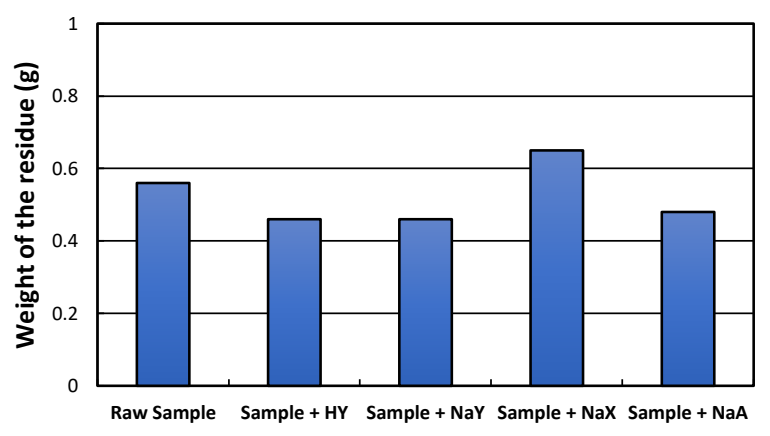

Figure 4 Weight of the residue after pyrolysis

From these results, faujasite-type zeolite including $\mathrm{Na}^{+}$is better materials for the conversion of rice straw into methane gas.

The behavior of the generated gas from rice straw using $\mathrm{NaY}$ zeolite was investigated.

Table 4 shows the amount of the gas generated from rice straw with various addition of $\mathrm{NaY}$ zeolite. Setting temperature is $400{ }^{\circ} \mathrm{C}$, and heating time is $1 \mathrm{~h}$. The generated amounts of gas from rice straw increase with the zeolite addition, and are almost same amount regardless of amount of zeolite addition. It is also noted that no pyrolysis oil was generated during the experiment.

Table 4 Amount of gas generated during the experiment.

Amount of gas (L)

\begin{tabular}{cc}
\hline Rice straw & 5.2 \\
\hline Rice straw $+0.5 \mathrm{~g} \mathrm{NaY}$ & 9.0 \\
\hline Rice straw $+1.0 \mathrm{~g} \mathrm{NaY}$ & 10.9 \\
\hline Rice straw $+2.0 \mathrm{~g} \mathrm{NaY}$ & 11.0 \\
\hline
\end{tabular}


Figure 5 shows the amounts of the gas generated from rice straw with various addition of $\mathrm{NaY}$ zeolite. With addition of $1.0 \mathrm{~g}$ of $\mathrm{NaY}$, higher amount of methane gas was produced than the others, while the amount of hydrogen decrease with increasing $\mathrm{NaY}$ addition and those of other gases are almost same regardless of $\mathrm{NaY}$ addition.

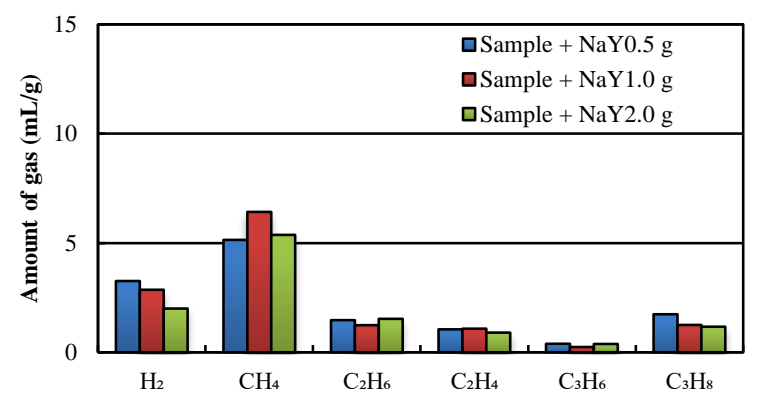

Figure 5 Amounts of various gases generated from rice straw with various addition of $\mathrm{NaY}$.

Figure 6 shows the weight of residue from rice straw with various addition of $\mathrm{NaY}$ zeolite. The weights of the residue are almost constant, which are correlated with amounts of generated gas.

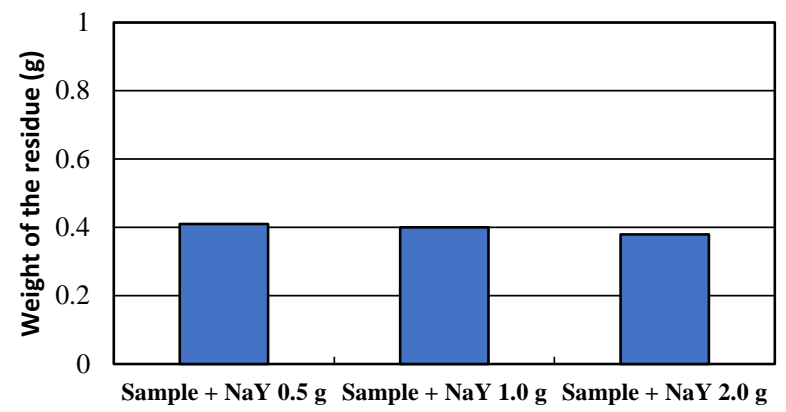

Figure 6 Weight of the residue after pyrolysis with various addition of $\mathrm{NaY}$.

From these results, the mixture of $1 \mathrm{~g}$ of rice straw and $1 \mathrm{~g}$ of $\mathrm{NaY}$ is better condition for the conversion of rice straw into methane gas.

Figure 7 shows the amount of gas generated from rice straw with $\mathrm{NaY}$ addition during the heating at various temperatures. The mixture of $1 \mathrm{~g}$ of rice straw and $1 \mathrm{~g}$ of $\mathrm{NaY}$ is used for this experiment. Regardless of temperatures, the amount of generated gas increases rapidly within $30 \mathrm{~min}$, and then be almost constant. With increasing the temperature to $500{ }^{\circ} \mathrm{C}$, the amount of generated gas increases.

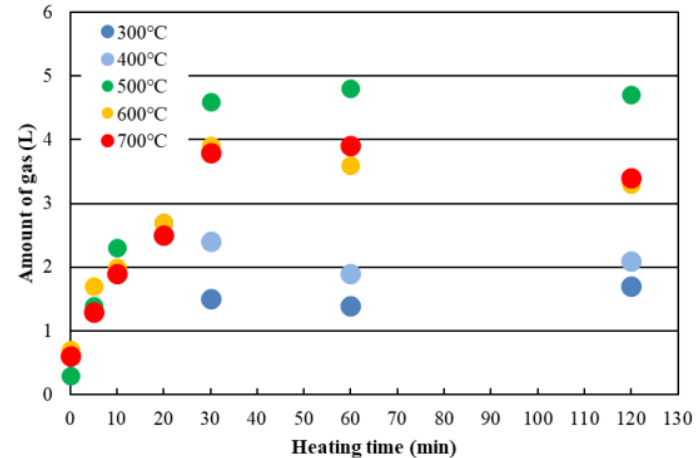

Figure 7 The amount of gas generated from rice straw with $\mathrm{NaY}$ addition during the heating at various temperatures.

Figure 8 shows the amount of various gases generated from rice straw with $\mathrm{NaY}$ addition during the heating at various temperatures. With increasing temperature, the amounts of all gases increases, while those of all gases gradually increase with increasing heating time.

Figure 9 shows the compositions of main gas species, $\mathrm{CH}_{4}, \mathrm{H}_{2}, \mathrm{CO}$ and $\mathrm{CO}_{2}$, in the generated gases from rice straw with $\mathrm{NaY}$ addition during the heating at (a) 500 ${ }^{\circ} \mathrm{C}$, (b) $600{ }^{\circ} \mathrm{C}$ and (c) $700{ }^{\circ} \mathrm{C}$. With increasing the heating time, compositions of $\mathrm{CO}$ and $\mathrm{CO}_{2}$ decrease and those of $\mathrm{H}_{2}$ and $\mathrm{CH}_{4}$ increase. With increasing the heating time to $120 \mathrm{~min}$, composition of methane gradually increases at $500{ }^{\circ} \mathrm{C}$, while those of methane almost constant at $600{ }^{\circ} \mathrm{C}$ and $700{ }^{\circ} \mathrm{C}$. In addition, composition of $\mathrm{H}_{2}$ is higher with increasing heating temperature. Therefore, the efficient conversion of rice straw into variable gas including methane can be done at more than $600{ }^{\circ} \mathrm{C}$ for $30 \mathrm{~min}$ with addition of $\mathrm{NaY}$ zeolite.

Figure 10 shows the reduction of the weight of residue after heating with $\mathrm{NaY}$ addition at various temperatures. With increasing the heating time, the weight of residue gradually decreases. The behaviors of decrease for the weight of residue are almost same at $500^{\circ} \mathrm{C}, 600^{\circ} \mathrm{C}$ and $700{ }^{\circ} \mathrm{C}$. The weights of the residue gradually decrease within $30 \mathrm{~min}$, and then become almost constant. The residual percent of the residue to rice straw after $30 \mathrm{~min}$ is approximately $10 \%$ above $500{ }^{\circ} \mathrm{C}$. 
(a)

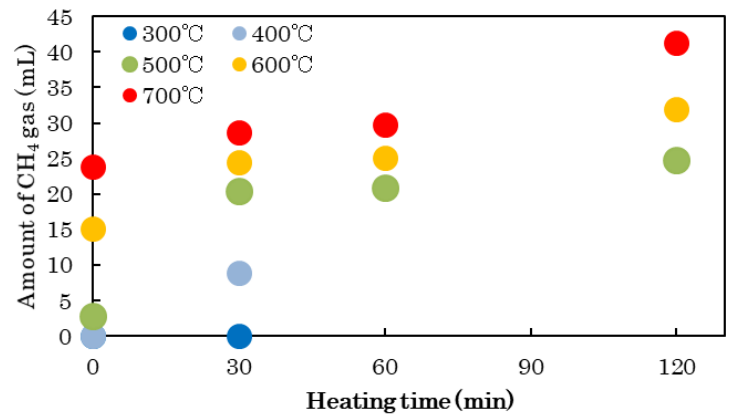

(b)

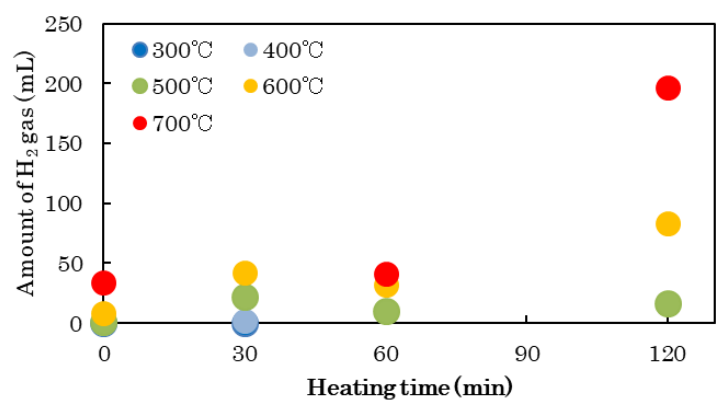

(c)

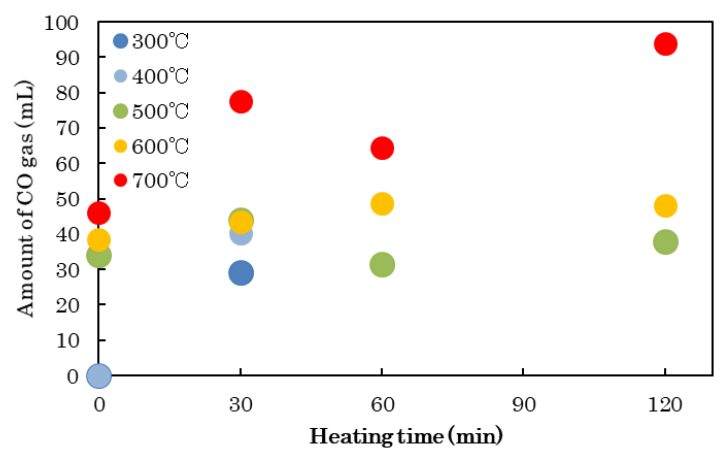

(d)

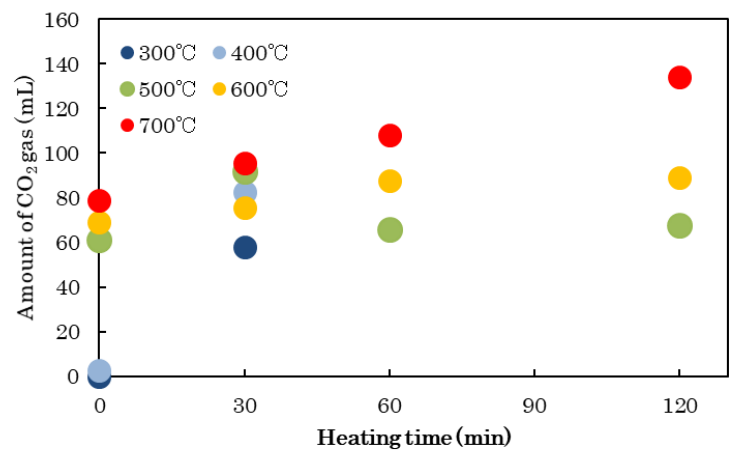

Figure 8 The amounts of various gases, (a) $\mathrm{CH}_{4}$, (b) $\mathrm{H}_{2}$, (c) $\mathrm{CO}$ and (d) $\mathrm{CO}_{2}$, generated from rice straw with $\mathrm{NaY}$ addition during the heating at various temperatures. (a)

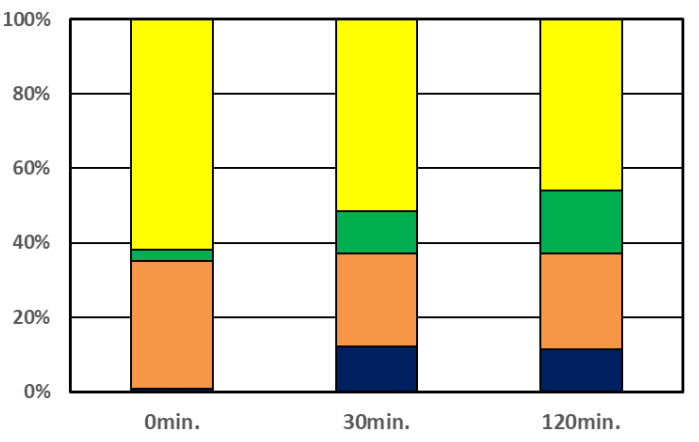

$\square \mathrm{H}_{2} \square \mathrm{CO} \quad \square \mathrm{CH}_{4} \quad \square \mathrm{CO}_{2}$

(b)

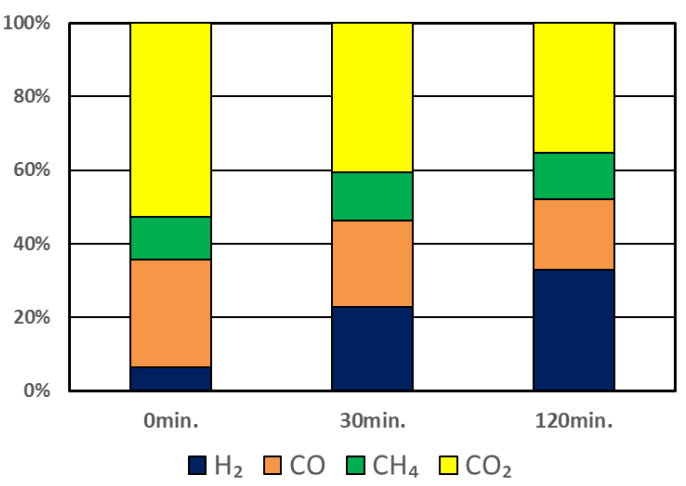

(c)

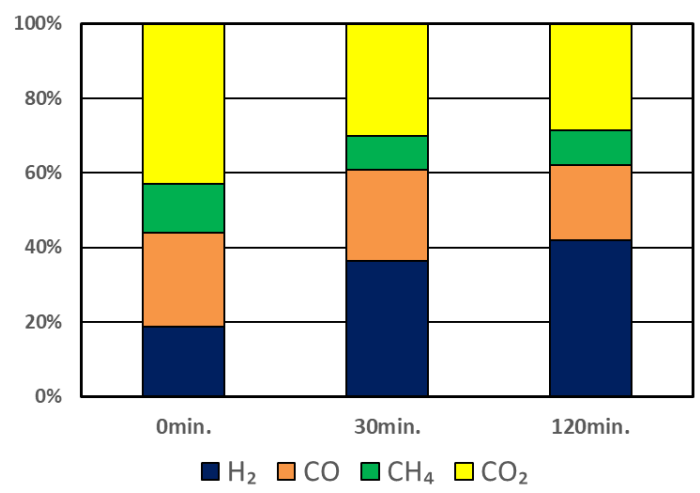

Figure 9 Compositions of main gas species, $\mathrm{CH}_{4}, \mathrm{H}_{2}, \mathrm{CO}$ and $\mathrm{CO}_{2}$, in generated gases from rice straw with $\mathrm{NaY}$ addition during the heating at (a) $500{ }^{\circ} \mathrm{C}$, (b) $600{ }^{\circ} \mathrm{C}$ and (c) $700{ }^{\circ} \mathrm{C}$. 


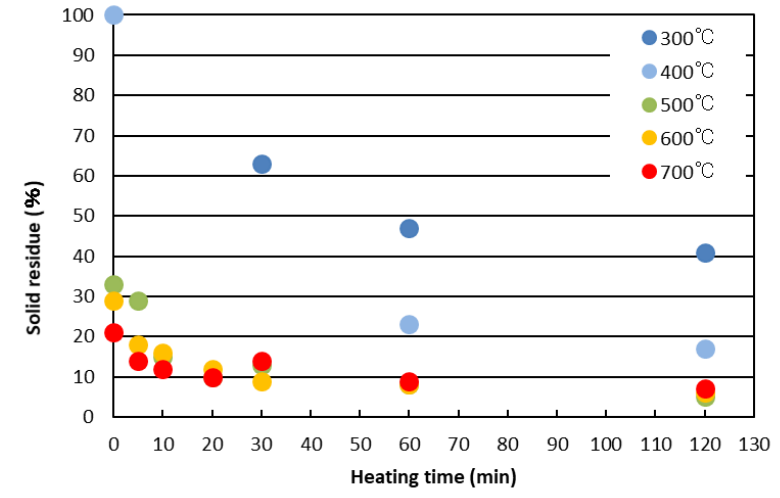

Figure 10 Reduction of the weight of residue after heating with $\mathrm{NaY}$ addition at various temperatures.

The experimental kinetic data were fitted using a pseudo-first-order kinetic model and a pseudo-secondorder kinetic model, shown in liner equation (1) and (2), respectively;

$$
\begin{aligned}
& \ln \left(w / w_{0}\right)=-k_{1} \cdot t \\
& 1 / w-1 / w_{0}=k_{2} \cdot t
\end{aligned}
$$

where $t$ is the measuring time ( $\mathrm{min}), w_{0}$ and $w$ are the residual weights at heating time $=0$ and measuring time, respectively, and $k_{1}$ and $k_{2}$ are the reaction rate constant of a pseudo-first-order kinetic model and a pseudosecond-order kinetic model, respectively. The results of parameters are shown in Table 5. The reaction behavior is found to fit second-order-kinetics model better than first-order-kinetic model. With increasing heating temperature, $w_{0}$ decreases, which means that a large part of the reaction occurs during the time for rising temperature to setting temperature.

Table 5 Parameters for kinetics models

\begin{tabular}{ccccccc}
\hline & \multicolumn{2}{c}{ First-order-kinetics } & \multicolumn{3}{c}{ Second-order-kinetics } \\
\cline { 2 - 7 } & $k_{1}$ & $w_{0}$ & $R^{2}$ & $k_{2}$ & $w_{0}$ & $R^{2}$ \\
\hline 300 & 0.0061 & 0.79 & 0.880 & 0.0107 & 0.79 & 0.925 \\
\hline 400 & 0.0081 & 0.29 & 0.993 & 0.0528 & 0.36 & 0.999 \\
\hline 500 & 0.0138 & 0.22 & 0.752 & 0.1334 & 0.29 & 0.930 \\
\hline 600 & 0.0109 & 0.18 & 0.732 & 0.1018 & 0.18 & 0.893 \\
\hline 700 & 0.0069 & 0.15 & 0.683 & 0.0661 & 0.15 & 0.807 \\
\hline
\end{tabular}

Figure 12 shows the photos of the residue after pyrolysis at (a) $300{ }^{\circ} \mathrm{C}$, (b) $400{ }^{\circ} \mathrm{C}$, (c) $500{ }^{\circ} \mathrm{C}$, (d) $600{ }^{\circ} \mathrm{C}$, and (e) $700{ }^{\circ} \mathrm{C}$ for $30 \mathrm{~min}$. Carbonization of rice straw can be observed at $400-700{ }^{\circ} \mathrm{C}$, while that cannot be observed at $300{ }^{\circ} \mathrm{C}$.

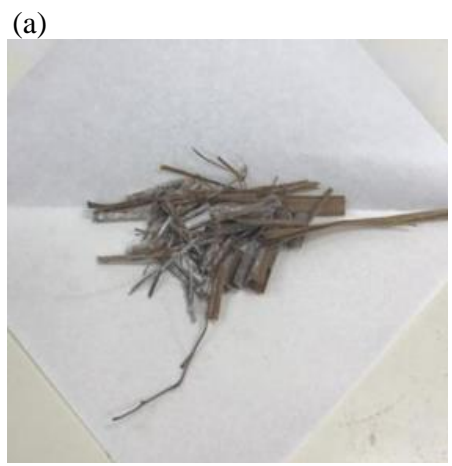

(b)

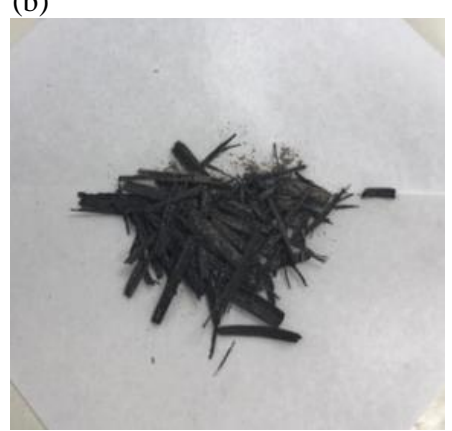

(c)

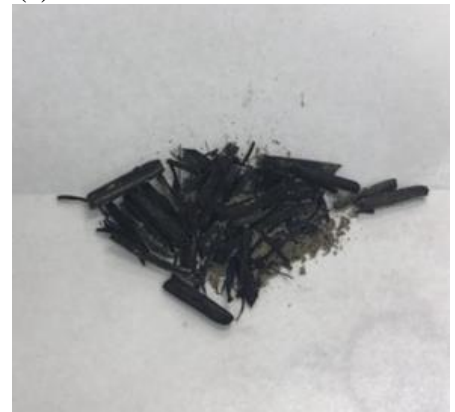

(d)

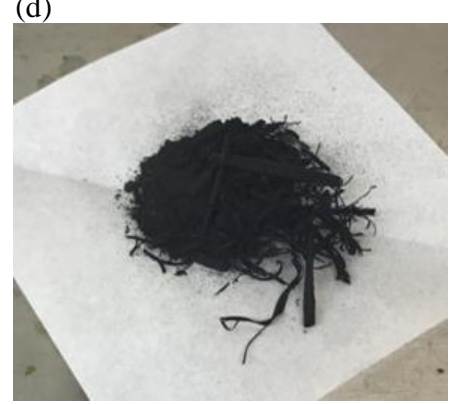

(e)

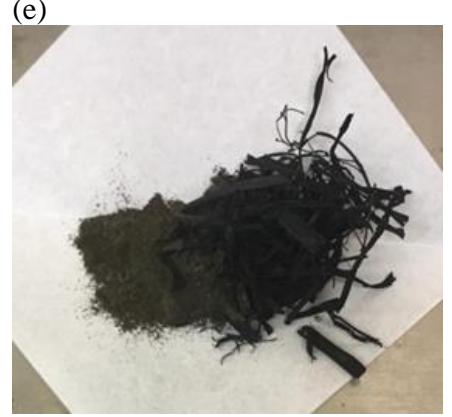

Figure 12 Photos of the residue after pyrolysis at (a) $300{ }^{\circ} \mathrm{C}$, (b) $400{ }^{\circ} \mathrm{C}$, (c) $500{ }^{\circ} \mathrm{C}$, (d) $600{ }^{\circ} \mathrm{C}$, and (e) $700{ }^{\circ} \mathrm{C}$ for $30 \mathrm{~min}$. 
Figure 13 shows XRD pattern of the mixture of rice straw and $\mathrm{NaY}$ before and after pyrolysis. There was no change of the zeolite crystal structure by the pyrolysis. In other words, the zeolite can keep the structure to be used as catalyst after pyrolysis.

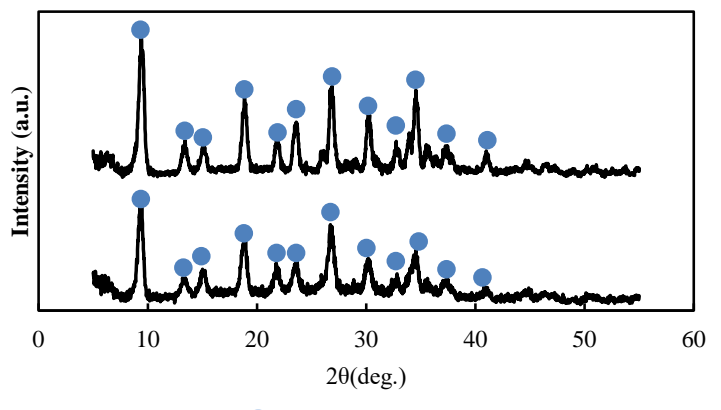

: NaY zeolite

Figure 13 XRD patterns of the the mixture of rice straw and $\mathrm{NaY}$ before and after pyrolysis.

\section{REFERENCES}

[1] Maniatis, K., Guiu, G., Riesgo, J. 2002. The European commission perspective in biomass and waste thermochemical conversion. In bridwater AV, editor. Pyrolysis and gasification of biomass and waste. Proceedings of an Expert Meeting, p. 1- 18.

[2] Kücük, M.M. and Demirbas, A. 1997. Biomass conversion processes. Energy Conversion and Management 38, 151-165.

[3] Pathak, B., Chaudhari, S. and Fulekar, M.H. 2013. Biomass-resource for sustainable development. International Journal of Advancements in Research \& Technology 2, 271-287.

[4] Sims R.E.H. 2003. Energy and Fuel Wood. Center for neregy research. Massey University.

[5] Lin, Y. and Tanaka, S. 2006. Ethanol fermentation from biomass resources: current state and prospects. Applied Microbiology and Biotechnology 69, 627642.

[6] Caputo, A.C., Palumbo, M., Pelagagge, P.M. and Scacchia, F. 2005. Economics of biomass energy utilization in combustion and gasification plants: effects of logistic variables. Biomass \& Bioenergy 28, 35-51.

[7] Yoshioka, T., Hirata, S., Matsumura, Y. and Sakanishi K.W. 2005. Biomass resources and conversion in Japan: the current situation and projections to 2010 and 2050. Biomass \& Bioenergy 29, 336-346.

[8] Yilmaz, S. and Selim, H. 2013. A review on the methods for biomassto energy conversion systems design. Renewable and Sustainable Energy Reviews 25, 420-430.

\section{CONCLUSION}

In this study, conversion of agricultural biomass waste, rice straw, into methane gas using the zeolite catalyst for utilization of the waste. Faujasite type zeolite having $\mathrm{Na}$ ( $\mathrm{NaX}$ and $\mathrm{NaY}$ ) produced the highest amount of methane to be used as fuel. The sample with $\mathrm{NaY}$ zeolite (sample : zeolite $=1: 1$ ) can generate high amount of methane, and the gas including high content of methane can be obtained at higher than $600{ }^{\circ} \mathrm{C}$ for $30 \mathrm{~min}$. The weight of the residue is approximately $10 \%$ of raw rice straw, and zeolite added into the reactor can keep the structure to be used as catalyst. NaY zeolite is effective additive for the production of high value gas including methane via pyrolysis of the biomass wastes.

\section{ACKNOWLEDGMENTS}

The authors acknowledge the financial support from Chiba University, Japan.

[9] Panwar, N.L., Kothari, R. and Tyagi, V.V. 2012. Thermo chemical conversion of biomass- ecofriendly energy routes. Renewable and Sustainable Energy Reviews 16, 1801-1816.

[10] Wang, Y., Dai, L., Fan, L., Duan, D., Liu, Y., Ruan, R., Yu, Z., Liu, Y. and Jiang, L. 2017. Microwaveassisted catalytic fast co-pyrolysis of bamboo sawdust and waste tire for bio-oil production. Journal of Analytical and Applied Pyrolysis 123, 224-228.

[11] Dai, L., Fan, L., Duan, D., Ruan, R., Wang, Y., Liu, Y., Zhou, Y. and Yu, Z. 2017. Microwave-assisted catalytic fast co-pyrolysis of soapstock and wastefire for bio-oil production. 125, 304-309.

[12] Rinaldi, R. and Schüth, F. 2009. Design of solid catalysts for the conversion of biomass. Energy and Environmental Science 2, 610-626.

[13] Serrano-Ruiz, J.C. and Dumesic, J.A. 2011. A catalytic routes for the conversion of biomass into liquid hydrocarbon transportation fuels. Energy and Environmental Science 4, 83-99.

[14] Perego, C. and Bosetti, A. 2011. Biomass to fuels: the role of zeolite and mesoporous materials. Microporous and Mesoporous Materials 